\title{
Estado, narcotráfico e sistema financeiro: algumas aproximações
}

\author{
Ney Jansen Ferreira Neto
}

\section{Resumo}

Neste artigo, buscamos fazer algumas aproximações entre o fenômeno do narcotráfico e mecanismos do sistema financeiro e de desregulamentação no capitalismo, compreendendo os determinantes estruturais da expansão do narcotráfico como um elemento importante de análise. Contrapomos as medidas de desregulamentação financeira e monetária com as medidas de regulamentação/fiscalização do dinheiro ilícito, além de analisar se existe interesse de Estados/ governos no capitalismo em combater os capitais ilícitos.

Palavras-chave: Narcotráfico. Lavagem de dinheiro. Sistema financeiro.

\section{Introdução}

Estado, narcotráfico e sistema financeiro. Uma teia de relaçóes sociais complexas que merecem uma especial atenção. Existem múltiplas dimensóes para o estudo do fenômeno do narcotráfico, que sáo analisadas pelas Ciências Humanas.

O motivador da expansão do comércio de drogas (lícitas e ilícitas) é o fato de este ser fundamentalmente um negócio rentável, graças ao alto consumo, que é incentivado por diferentes mecanismos na sociedade capitalista.

O narcotráfico é um fenômeno historicamente recente, adquirindo grande dimensão na segunda metade do século XX. Inicialmente, o narcotráfico pode ser definido como uma forma de acumulaçáo mercantil inserida em relaçóes sociais que envolvem uma diversidade de atores: produtores, traficantes, instituiçóes financeiras, instituiçóes estatais, tráfico formiguinha, mercado consumidor.

I Mestre em Sociologia Politica pela Universidade Federal de Santa Catarina (UFSC), Florianópolis, Santa Catarina, Brasil.Professor de Sociologia da rede estadual do Paraná.E-mail:ney_cs@yahoo.com.br. 
Muitas políticas públicas e o aparato repressivo dos Estados no século XX e início do XXI estiveram voltados para os elos mais fracos da cadeia mercantil: a repressão aos camponeses cultivadores, a repressáo ao varejo, a criminalizaçáo do usuário.

Os elos ocultos desse processo mercantil seriam a pouca atençáo midiática que se dá ao papel intencional e sistemático dos bancos e ao papel específico do sistema global de paraísos fiscais, que promovem a acumulação de imensas dívidas públicas, ao lado da acumulaçáo de consideráveis bens privados no exterior (WOODIWISS, 2007). Segundo Woodiwiss (2007), "crime organizado" passou a estar associado a fatos desafortunados da natureza humana e não às políticas do Fundo Monetário Internacional (FMI) e Banco Mundial, que sáo vistas quase exclusivamente como do reino "da economia", sem ligaçáo com o florescimento e expansáo do crime organizado.

\section{Hipótese: crises de liquidez e dirty money}

A atual crise financeira global está assentada numa necessidade permanente de liquidez (capital dinheiro) no sistema bancário/financeiro. Na prática, significa que o atual arranjo sociopolítico do sistema financeiro mundial alimenta-se cada vez mais de uma apropriaçáo da renda do trabalhador via sistema de crédito e da apropriação de rendas do Estado, via desmantelamento dos serviços e orçamentos públicos, para se resgatar/salvar os bancos. Essa "crise de liquidez" é particularmente importante, pois nos leva a pensar até que ponto as medidas para se combater a lavagem de dinheiro, por exemplo, são de interesse do sistema financeiro.

Nos últimos anos, alguns dos principais bancos e instituiçóes financeiras, como o Wells Fargo, Bank of America, Citigroup, American Express, Western Union, $H S B C$, foram acusados de lavar dinheiro do narcotráfico.

Segundo o documento Estimating illicit flows resulting from drug trafficking and other transnational organized crimes, documento sobre receitas do crime organizado e lavagem de dinheiro do United Nations Office On Drugs and Crime (UNODC) de 2011, a movimentaçáo seria da ordem de US\$2,1 trilhóes, equivalente a 3,6\% do Produto Interno Bruto (PIB) global (de US\$ 58 trilhóes em 2009).

Segundo dados do referido relatório do UNODC, a estimativa mínima do valor movimentado globalmente pelo narcotráfico seria de US\$349,9 bilhóes (correspondente a 17\% das receitas globais do crime organizado) e 
a estimativa máxima de US\$ 524,9 bilhóes (correspondente a $25 \%$ dessas receitas globais).

A média entre os $17 \%$ e os $25 \%$ movimentados pelo narcotráfico seria algo em torno de US\$ 420 bilhóes (20\% das receitas globais do crime organizado), e a lavagem de dinheiro do narcotráfico corresponderia a cerca de 13,8\% (US\$291,6 bilhôes, média entre estimativas mínima de 11\% e máxima de 16,6\%) das receitas globais do crime organizado.

O valor médio movimentado pelo narcotráfico (US\$ 420 bilhōes, média entre $0,6 \%$ e $0,9 \%$ do PIB global de 2009) é um determinante náo apenas quantitativo, mas determinante qualitativo na atual conjuntura econômica global e articulado com diversos ramos da economia legal e ilegal (Tabela 1).

Tabela I - Estimativas do UNODC de receitas e lavagem de dinheiro do tráfico de drogas em 2009

\begin{tabular}{|c|c|c|}
\hline Estimativas & US\$ trilhões & $\begin{array}{l}\text { PIB mundial em 2009: } 58,3 \\
\text { trilhões } \\
\text { Participação em relação ao } \\
\text { PIB (\%) }\end{array}$ \\
\hline $\begin{array}{l}\text { Receitas globais } \\
\text { (crime organizado) }\end{array}$ & 2,I trilhões (média) & 3,6 (média de 2,3 a 5,5) \\
\hline $\begin{array}{l}\text { Lavagem global } \\
\text { (crime organizado) }\end{array}$ & $\begin{array}{l}\text { 1,6 trilhão (média) } \\
\text { (\% das receitas globais do } \\
\text { crime: } 76,19 \% \text { ) }\end{array}$ & 2,7 (média de 2,I a 4) \\
\hline $\begin{array}{l}\text { Receitas globais } \\
\text { (drogas ilícitas) }\end{array}$ & $\begin{array}{l}349,9 \text { bilhões ( } 17 \%) \text { a } 524,9 \\
\text { bilhões }(25 \%) \\
\text { Média: } 420 \text { bilhões } \\
\text { (\% nas receitas globais do } \\
\text { crime: } 20 \%)\end{array}$ & 0,6 a 0,9 \\
\hline $\begin{array}{l}\text { Lavagem global } \\
\text { (drogas ilícitas) }\end{array}$ & $\begin{array}{l}233,3 \text { bilhões ( } 11 \%) \text { a } 349,9 \\
\text { bilhões (16,6\%) } \\
\text { Média: } 291,6 \text { bilhões } \\
\text { (\% nas receitas globais do } \\
\text { crime: } 13,8 \%)\end{array}$ & 0,4 a 06 \\
\hline
\end{tabular}

Fonte: elaborada pelo autor sobre dados de UNODC (2011). 
Segundo Antônio Maria Costa, diretor do UNODC, em declaraçáo em janeiro de 2009, bilhóes de dólares foram empregados para se impedir a quebra do sistema financeiro durante a última grande crise econômica mundial:

Durante o segundo semestre de 2008, a falta de liquidez foi o principal problema do sistema bancário e o capital disponível tornou-se um fator fundamental. Em muitos casos, o dinheiro da droga foi o único capital de investimento disponível. Muitos bancos foram salvos da crise financeira graças ao dinheiro das drogas. (DINO; MAIEROVITCH, 20I0, p. 21).

Se os valores movimentados pelo narcotráfico atuam de maneira a colocar mais água no moinho da circulaçáo mundial de capitais, como afirmamos, nossa atenção está em primeiro lugar no dinheiro.

De acordo com estudos de Machado (s/d), o que caracteriza o atual sistema financeiro sáo os novos arranjos espaciais via lavagem de dinheiro, fluxos de capitais de curto prazo (hot money/dirty money) e altas taxas de juros. O hot money seria o dinheiro especulativo. O dirty money seria o dinheiro "sujo". Segundo Machado, a origem do dinheiro é dissolvida ao adentrar no sistema financeiro:

As tentativas de diferenciação desses diversos 'tipos' de dinheiro partem de um conjunto de pressupostos bastante discutíveis: o pressuposto conceptual, de que seria possivel manter o 'certificado de origem' do dinheiro depois que ele entra no sistema bancário e financeiro; o pressuposto de que é possível uma transferência do sentido de moralidade da esfera privada para a esfera pública, ao se querer atribuir ao dinheiro movido na esfera das instituições sociais um sentido moral, ético, autônomo, semelhante às restrições operantes na circulação de dinheiro na esfera privada (do indivíduo); o pressuposto de uma única e monolítica condição de legalidade das práticas bancárias e financeiras, independente de sua contextualização social, geográfica e política. (MACHADO, 2008).

Ao se pensar em lavagem de dinheiro, existem duas dimensóes desse fenômeno. Uma é a dimensão de caráter normativo, no que se refere àquilo que é ilícito, ilegal, perante o Estado; e a outra é a dimensão referente ao método, no que se refere ao processo de ocultaçấo, dissimulaçáo, de ativos e bens.

Essas duas distinçóes na literatura sobre o tema apresentam-se em duas famílias de palavras. As expressóes em francês blanchiment d'argent e em espanhol blanqueo de dinero são expressóes que se referem ao resultado, ao objetivo da lavagem, ou seja, o seu "branqueamento", tornar legal, limpo, lícito um dinheiro de origem ilícita. Tais expressóes são utilizadas pela literatura francesa e espanhola. As expressóes em inglês money laudering e no alemáo geldwäsche 
referem-se ao ato em si, a açáo de lavagem. No português brasileiro, nos textos jurídicos e nos órgãos de fiscalização no Brasil (o Conselho de Controle de Atividades Financeiras [Coaf]), optou-se pela expressáo "lavagem de dinheiro" compartilhada no inglês e no alemão (JOBIM, 1999).

As três etapas da lavagem de dinheiro são a colocaçáo, a lavagem e a integraçáo. Segundo Machado (1997, 2008) e Novaes (2003), existe uma diferenciaçáo entre "rede de tráfico" e "rede de lavagem". A primeira rede seria mais flexível, pois apresentaria uma dependência menor de serviços específicos num determinado território (cidade), facilitando a rota das mercadorias ilegais. A rede de tráfico trata do transporte físico das mercadorias.

A segunda rede (a rede de lavagem) seria menos flexível, apresentando risco pelo menos na primeira etapa, a que Novaes (2003), seguindo o mesmo modelo da cartilha do Coaf (BRASIL, 2005), chamará de "colocaçáo", ou seja, de depósito em espécie em um banco. No entanto, a etapa inicial de colocação pode ocorrer em qualquer cidade, bastando ter uma única agência bancária. Os fracionamentos dos depósitos ocorrem aqui. A segunda etapa seria a de "acomodaçáo" via transferências bancárias múltiplas. Tais operaçôes seriam de baixo risco. Por fim, a terceira etapa, a da "integraçáo", via investimento desse dinheiro na economia legal, também seria de baixo risco.

Porém, há uma dificuldade em se isolar os narcodólares, agravada pelas diferentes maneiras de lavagem de dinheiro: transaçôes abaixo de 10 mil dólares, transferências eletrônicas, compra de cheques bancários, casas de câmbio, subfaturamento ou superfaturamento de exportaçóes, entre outros. Nas regióes onde há uma grande movimentação financeira mesclada com diversas atividades produtivas e comerciais, a tarefa de identificaçáo do dinheiro ilícito é mais difícil. Mas a aglomeraçáo de bancos e instituiçóes financeiras, a proporção de transaçóes bancárias e financeiras externas e a quantidade e variedade de serviços especializados oferecidos sáo alguns dos indicadores da localizaçáo dos principais centros bancários e financeiros.

O capitalismo atual nunca foi táo propício a aplicaçóes, transferências e especulaçóes beneficiadas pelas inovaçóes tecnológicas e pelas operaçóes em rede do sistema bancário e financeiro. Esse domínio operacional dos meios tecnológicos ligados ao poder econômico está ligado à existência dos hot money, estando "muitos distantes das realidades cotidianas, das necessidades humanas e de toda possibilidade normal de controle" (CERVINI, 1997, p. 204). 
A análise do papel do Estado na política de liberalizaçáo do movimento dos capitais visa à compreensão de algumas simbioses entre narcotráfico e sistema financeiro.

\section{Identificando medidas de desregulamentação}

A adesão ao princípio da livre mobilidade de capitais que incluíram um processo global de desregulamentaçáo monetária e financeira, a criação de um mercado privado interbancário e a explosão de paraísos fiscais ocorreram em ritmos diferentes em cada país. No caso dos países periféricos, como na América Latina, a abertura externa de seus sistemas financeiros deu-se sob pressáo de uma política de endividamento crescente, via "abundância de crédito" (CHESNAIS, 1996), casada com políticas de privatizaçáo de empresas estatais, desindustrializaçáo e desemprego acelerado sob pressáo expressa de organismos multilaterais. Essas políticas de "acumulação via espoliação" (HARVEY, 2010) foram os condicionantes estruturais para o desenvolvimento do fenômeno do narcotráfico a partir dos anos 1970/1980. O narcotráfico seria "o filho mais novo do imperialismo" segundo Coggiola (1991, 2005), no sentido de que existe uma relaçáo entre capital financeiro, imperialismo e expansão da produçấo e consumo de drogas.

A narcoeconomia na América Latina alimentou-se de processos de desindustrializaçáo e privatizaçóes, resultando em um processo de narcorreciclagem das economias agrárias e de liberalizaçáo dos mercados, com a queda dos preços das matérias-primas no mercado mundial, afetando camponeses que passaram a dedicar-se ao cultivo de drogas pela sua rentabilidade - caso da Bolívia, Colômbia, Peru - (COGGIOLA 1991).

Segundo relatórios do UNODC, em 1988 o narcotráfico movimentava cerca de US\$ 124 bilhóes. Em 2003, US\$ 322 bilhôes. Em 2009, US\$ 420 bilhóes, sendo que o valor movimentado pelas drogas ilícitas em 2003 era superior ao PIB de 88\% dos países do mundo (ou 163 de 184 países). Em 2003, o comércio de drogas ilícitas movimentou o equivalente a $12 \%$ das exportaçóes mundiais de produtos químicos (US\$ 794 bilhóes) e a 14\% das exportaçóes agrícolas mundiais (US\$ 674 bilhóes) e foi superior às exportaçóes de minérios (US\$ 79 bilhóes), à exportaçáo de produtos agrícolas pela América Latina (US\$ 75 bilhôes) e às exportaçóes agrícolas do Oriente Médio, que somaram cerca de US\$ 10 bilhóes (UNODC, 1997 a 2012). Isso 
ajuda a explicar o interesse de setores do agronegócio e do capital financeiro na legalização das drogas ilegais (Tabela 2).

Tabela 2 - Valores movimentados pelo tráfico de drogas (1988, 2003, 2009)

\begin{tabular}{l|c|c|c|c}
\hline Ano & $\begin{array}{c}\text { Movimentação do tráfico } \\
\text { de drogas (US\$ bilhões) }\end{array}$ & $\begin{array}{c}\text { \% do PIB global } \\
\text { (média) }\end{array}$ & $\begin{array}{c}\text { Lavagem de dinheiro } \\
\text { (US\$ bilhões) }\end{array}$ & \% do PIB global \\
\hline 1988 & 124 & 0,8 & 85 & 0,5 \\
\hline 2003 & 322 & 0,9 & 220 & 0,6 \\
\hline 2009 & 420 & 0,7 & 233 & 0,5 \\
\hline
\end{tabular}

Fonte: elaborada pelo autor com base em dados do UNODC.

Ocorreu uma política permissiva em relação à livre circulaçáo de capitais, através da adoçáo da flexibilizaçáo cambial, da flexibilizaçáo da entrada/saída de capitais, com a sobrevalorização das moedas locais, o que permitiu que os narcodólares em abundância pudessem entrar e sair, sem exigências das provas de sua origem por parte dos Bancos Centrais de determinados países. Tais açóes ocorreram em países como Bolívia, Brasil, Colômbia, Peru e México nas décadas de 1970 e 1980 (UPRIMNY, 1997; GROSSE, 2001; SANCHÉZ, 1993; DEL ROIO, 1997; PEREIRA, 2010; CAMPS, 1995; LIMA, 2006). Essas medidas foram justificadas pela "realidade do mercado", tornando-se propícias à lavagem de dinheiro.

Esses "mercados negros" (black markets) ou "mercados paralelos" (parallel markets) puderam desenvolver-se na América Latina pois, nesse subcontinente, a adoção de medidas de liberalizaçáo financeira permitiu, por exemplo, que instituiçôes náo bancárias pudessem prestar serviços de câmbio. Tais segmentos são um verdadeiro canal para a lavagem de dinheiro.

No caso mexicano, durante o Tratado Norte-Americano de Livre Comércio (Nafta), o livre movimento de capitais, a intensa privatizaçáo das empresas estatais e o aumento de demissóes nos setores público e privado tiveram como consequências a queda do poder aquisitivo das famílias, o aumento das atividades do setor informal e o desemprego no campo, fruto da política de abertura comercial com a intensificação das migraçóes. Tais medidas facilitaram a emergência de poderosos cartéis da droga, encontrando uma populaçáo em situaçáo de pobreza generalizada, além da participação desses cartéis no processo de compra de açóes de empresas públicas privatizadas (CAMPS, 1995). 
O caso boliviano também exemplifica como o narcotráfico pode expandir-se como consequência de políticas liberalizantes. Durante o governo do presidente Victor Paz Estenssoro (1985-1989), editou-se no dia 29 de agosto de 1985 o Decreto Supremo (DS) no 21.060, que declarava que todas as moedas cotadas podiam ser depositadas nos bancos bolivianos, em qualquer quantidade e sem controle nenhum, com respeito total ao sigilo bancário em relaçáo à sua proveniência. Ao comentar sobre esse decreto, Del Roio afirma:

Em 1985, numa situação de caos, vence uma coalização neoliberal. Foi aplicada uma política econômica que levou os índices de desemprego a 30\%. As mineiras são fechadas, as atividades produtivas paralisadas e o que restava de Estado social, desmantelado. O Fundo Monetário Internacional aconselha e pressiona para a liberalização geral. O presidente Paz Estenssoro, com o decreto DS 21.060 declara que todas as moedas cotadas podem ser depositadas nos bancos bolivianos, em qualquer quantidade e sem controle nenhum, com respeito total ao sigilo bancário em relação a sua proveniência. Os aplausos dos organismos econômicos internacionais foram generalizados. Significou o sinal verde para grandes investimentos na coca. Ela se transformou em fonte de sustento para uma boa parte dos bolivianos, mergulhados na miséria. Aconteceu que em pouco tempo no planalto de Chapare, o melhor terreno para a plantação, a população passou de 20 mil habitantes para 200 mil. Caso quase único de esvaziamento das cidades e retorno ao campo. (DEL ROIO, 1997, p. 118, grifo nosso).

O DS no 21.060 foi revogado pelo governo de Evo Morales através do Decreto no 28.699, de 2006, atendendo assim a uma reivindicaçáo da Central Obrera Boliviana (COB).

\section{E no Brasil?}

A partir do final dos anos 1980 e do início dos anos 1990, ocorreu um processo de liberalizaçáo financeira na economia brasileira. Recursos passaram a ser enviados e recebidos do exterior, sem quaisquer restriçóes. Os governos responsáveis por essas medidas foram o governo de José Sarney (1985-1990), Fernando Collor (1990-1992) e Fernando Henrique Cardoso (1995-2002).

Essas políticas, originadas principalmente nos Estados Unidos e Inglaterra, iniciaram um processo de concessão de créditos abundantes (CHESNAIS, 1996) aos países do outrora chamado "Terceiro Mundo", com o rentável negócio dos títulos da dívida pública, expressão da acumulaçáo parasitária e financeira do atual estágio do capitalismo. $\mathrm{Na}$ América Latina, os escombros 
dessa política de endividamento dos Estados latino-americanos nos anos $1980 \mathrm{e}$ 1990, associados a medidas liberalizantes, de flexibilização cambial, flexibilizaçáo dos fluxos financeiros, privatizaçáo, como relatados aqui nos casos da Bolívia, Peru, Colômbia e México, propiciaram o florescimento da narcoeconomia, como subproduto de um processo mais amplo de piora dos indicadores sociais.

Nos anos 1990 no Brasil, esse endividamento, conjugado às medidas adotadas para conquistar a "estabilidade da moeda" e conter a inflação (abertura dos portos aos produtos importados, manutençáo do dólar barato, elevaçáo das taxas de juros, liberalização da movimentação dos fluxos financeiros), abriu o país para a entrada de capital especulativo. A livre movimentaçáo de capital foi estimulada pelo crescente afrouxamento da legislação fiscal e cambial. O ponto de partida do processo de liberalizaçáo financeira no Brasil foi a Resolução no 1.832, de 1991 (LEAL; RÊGO, 1997) do Conselho Monetário Nacional, que aprovou o "Anexo 4" a uma resoluçáo de 1987 (no 1.289/1987). O "Anexo 4" permitiu a entrada de investidores estrangeiros no mercado acionário doméstico, mantendo o anonimato dos responsáveis pelos fundos estrangeiros que investiam no país. As contas CC-5 (abreviação de Carta Circular no 5 do Banco Central) passaram a ser o único tipo de contas que não estava sujeito a nenhum tipo restriçáo a qualquer forma de aplicaçáo.

No Brasil, quando se pensa em medidas que buscaram relaxar o controle de entrada e saída de divisas, há que se destacar o histórico das contas CC-5 e seus desdobramentos nos anos 1990. A criação das CC-5, que foi editada pelo Decreto-Lei no 1.060 , de 1969, permitiu que contas fossem destinadas a pessoas físicas ou jurídicas que residiam no exterior mas que podiam movimentar dinheiro nas contas nacionais. ${ }^{2}$

No entanto, a terminologia "CC-5", embora utilizada no mercado, náo é mais apropriada, pois ocorreram mudanças a partir dos anos 1990. Esse processo de liberalizaçáo na década de 1990 foi marcado pela Resoluçáo $\mathrm{n}^{\circ} 1.552$, de 22 de dezembro de 1988, que passou a autorizar que bancos credenciados no país pudessem comprar e vender moeda estrangeira de e para instituiçóes financeiras no exterior. $\mathrm{O}$ mercado passou a chamar esse processo de “operação CC-5". No entanto, a CC-5 apenas regulamentava a abertura

2 O texto da Carta Circular $n^{\circ} 5$ do BC pode ser acessado no texto da Revista do TCU de julho-setembro de 200I, disponivel em: <http://portal2.tcu.gov.br/portal/pls/portal/docs/683670.PDF>. 
e movimentaçáo de contas por náo residentes e o Relatório do Tribunal de Contas da União (TCU, 2001) advertia que a utilização, sem nenhuma restriçáo, de moeda nacional e sua conversáo para instituiçáo financeira no exterior eram fruto da Resolução no 1.552, de 1988.

Em maio de 1998, a Comissão de Fiscalização Financeira e Controle da Câmara de Deputados solicitou um relatório ("Relatório da Auditoria Operacional da Sistemática de Operaçáo das Contas CC-5") para se apurar denúncias de utilizaçáo irregular das contas CC-5. O relatório foi entregue em junho de 1999 e publicado na Revista do TCU de julho-setembro de 2001.

Em 1989, no final do governo Sarney, ocorreram o início da abertura cambial e a regulamentaçáo do Mercado de Câmbio de Taxas Flutuantes (MCTF), através da Carta Circular no 1.402, de 2 de janeiro de 1989. O MCTF atribuiu um novo viés com o fim do controle rígido de remessas ao exterior e a autorizaçáo a instituiçóes financeiras, hotéis, agências de turismo (segmentos propícios à lavagem de dinheiro) para que realizassem operaçóes de câmbio. Tais contas passaram a ser usadas para a livre circulaçáo de moeda estrangeira entre o país e o exterior. O Conselho Monetário Nacional autorizava o Banco Central (BC) a credenciar instituiçóes financeiras e agências de turismo e hotéis para realizar operaçóes de câmbio a taxas convencionadas entre as partes, o que criava um mercado interno de moeda estrangeira (conhecido como "dólar turismo"). Tais segmentos de turismo são propícios à lavagem de dinheiro.

Em 22 de junho de 1989, ocorreu uma alteração no regulamento, através da Circular no 1.500 , sem que a Circular no 1.402 fosse revogada. Segundo a Circular $n^{\circ} 1.500$, citada no relatório do TCU,

6. As instituições bancárias credenciadas podem, da mesma forma, e independentemente de consulta ao Banco Central, realizar operações de compra e venda de moeda estrangeira com instituições financeiras no exterior, contra moeda nacional, vedada a prática dessas operações entre instituições coligadas.

7. As operações de que trata o item anterior devem ser escrituradas a débito/crédito das contas patrimoniadas representativas de direitos e obrigações em moeda estrangeira, em contrapartida com a rubrica, depósitos de domiciliados no exterior, em nome do parceiro da transação. (TCU, 2001, p. 23 grifo nosso).

Em publicaçáo editada em novembro de 1993 pelo Banco Central, intitulada $O$ regime cambial brasileiro - evoluçáo recente e perspectivas, também 
conhecida como Cartilha CC-5, a mudança de rumo se justificava, entre outras coisas, pela "realidade do mercado" e pelo fato de que "a inserção da economia brasileira nos circuitos financeiros internacionais requer maior mobilidade de capitais" (TCU, 2001, p. 20). O mesmo relatório do TCU admitia que "outra condição importante consistia na permissáo para que o vendedor náo se identificasse, o que abria a porta para atrair de volta ao país recursos de origem ignorada, pertencentes a brasileiros, que se encontravam depositados no exterior" (TCU, 2001, p. 20, grifo nosso).

O relatório do TCU destacou ainda:

Durante a fase de implantação sistemática das Contas CC-5, não houve preocupação com o aspecto do controle dessas contas e com a questão da identificação, tarefa dificultada pela formatação dada à mecânica das transferências:

a) o depósito em Contas CC-5 de instituição financeira não gerava, obrigatoriamente e no mesmo dia, uma remessa internacional, podendo ocorrer descasamento de prazos e valores, cujo rastreamento era dificultado pela inflação elevada;

b) podia haver operações em cadeia, por meio de transferências prévias entre Contas CC-5 mantidas em várias instituições financeiras, de várias praças, que exigiriam um rastreamento que tinha chances de chegar a resultados inconclusivos,

c) era possivel o depósito em espécie, que não produzia documentação hábil para comprovação de origem. (TCU, 200I, p. 25-26, grifos nossos).

O fato é que no Brasil, ao se permitir a criação de taxa de câmbio flutuante, permitia-se que a taxa fosse "regulada" pela oferta/procura de moeda estrangeira. Por sua vez, a compra de moeda estrangeira sem identificaçáo criava um verdadeiro canal para lavagem de dinheiro e afluxo de capital estrangeiro no país, desvalorizando o dólar (atraído por altas taxas de juros) e sobrevalorizando a moeda nacional, o que resultava em dificuldades para a exportaçáo da indústria nacional.

Em 1992, o Banco Central modificou os controles - através da Carta Circular no 2.259/1992 - no sentido de identificar e reunir condiçóes de identificar a origem e o destino dos recursos. Essa resoluçáo determinou a obrigatoriedade de se identificar os depositantes e sacadores de moeda nacional em espécie nas contas CC-5 de valor acima de US\$ 10 mil. Determinou-se também que as transferências internacionais fossem realizadas somente entre bancos e náo mais entre pessoas e bancos. No caso de operaçóes efetuadas com instituições financeiras não residentes, os bancos restringiam-se a alimentar o 
Sistema de Informaçáo do Banco Central (Sisbacen) com informaçóes financeiras das operaçóes cambiais e o nome das instituiçóes envolvidas.

No entanto, os problemas continuaram: os cheques de contas CC-5 náo tinham modelo próprio e se misturavam com os das contas comuns; um banco brasileiro podia abrir CC- 5 de um banco não residente, sem ter a obrigação de avisar o Banco Central; qualquer banco estrangeiro podia abrir conta no Brasil, dependendo das normas do país de origem e náo das normas brasileiras; não havia limites ou controles sobre depósitos (TCU, 2001).

A Circular no 2.677/1996 do Banco Central determinou que só seriam aceitos depósitos em CC-5 em dinheiro e, portanto, sem identificação, até o valor de R \$ 10 mil. Mas, no mesmo ano, o entáo Diretor de Assuntos Internacionais do Banco Central, Gustavo Franco, concedeu autorizaçáo especial para que cinco bancos, operando em Foz do Iguaçu (Banco do Brasil; Banco do Estado de Minas Gerais (Bemge); Banco do Estado do Paraná (Banestado), liquidado em 2000; Banco Araucária, liquidado em 2001; e Banco Real) recebessem o depósito de valores superiores aos $\mathrm{R} \$ 10$ mil permitidos e enviassem ao exterior, constando como remetente a própria instituiçáo financeira, fazendo depósitos sem identificaçáo do depositante, em contas CC-5. Dessa forma, esses depósitos em CC-5 poderiam, em seguida, ser convertidos em dólares e enviados livremente para o exterior.

$\mathrm{O}$ argumento de Gustavo Franco era de que o número de sacoleiros que faziam suas compras em Ciudad Del Este, no Paraguai, a cinco quilômetros de Foz do Iguaçu, pagando em reais, era grande. Os lojistas trocavam seu dinheiro nas casas de câmbio, que o depositavam em suas contas CC-5 no Brasil, transferindo-o em seguida para as CC-5 das instituiçóes financeiras no Paraguai.

A justificativa apresentada por Gustavo Franco náo conferiu com investigaçóes da Polícia Federal. Funcionários da área de fiscalização observaram que os depósitos em dinheiro feitos nas CC-5 eram bem superiores aos valores transportados pelos carros-fortes que atravessavam a fronteira Brasil-Paraguai. Além disso, parte do dinheiro depositado nas contas CCs-5 de Foz do Iguaçu sequer provinha do Paraguai, e também náo retornava em dólares para Ciudad del Leste. O dinheiro provinha de várias partes do Brasil (através de contas de laranjas), era sacado em Foz e depositado em dinheiro nas CC-5, como se fosse proveniente dos sacoleiros. Dessa forma, ficou extremamente 
difícil identificar os autores das remessas, que se utilizavam desse expediente para lavar dinheiro.

As "autorizaçóes especiais" concedidas às agências dos cinco bancos em Foz do Iguaçu para acolhimento de depósitos acima dos US\$ 10 mil sem identificação só foram canceladas por intermédio de voto do Banco Central, com a Resoluçáo no 490/1999, após reuniāo da diretoria do banco em 28 de dezembro de 1999, depois da saída de Gustavo Franco do Banco Central. Nas tabelas a seguir (3 a 5), apresentamos a descriçáo dos perfis e da movimentaçáo via CC-5 citados no relatório do TCU de 2001.

Percebemos, na tabela 3, um crescente de saída de capitais no período entre 1991 e 1998. Saíram R\$ 126 bilhóes ante a entrada de R 42 bilhóes, com um saldo negativo de $\mathrm{R} \$ 83$ bilhóes. A tabela 4 indica que o número de operaçóes mais utilizado por faixas de valores no período 1992-1998 foi entre $\mathrm{R} \$ 10$ mil e R \$ 500 mil. Importante destacar que, nesse período de 1991 a 1998, não vigorava ainda a Lei no 9.613/1998, a lei antilavagem no Brasil.

Tabela 3 - Ingressos e saídas de divisas relativas às contas de domiciliados no exterior (CC-5) de 1991 a 1998, em milhões de reais

\begin{tabular}{l|c|c|c}
\hline \multirow{2}{*}{ Período } & \multicolumn{3}{|c}{ Operações com instituições no exterior } \\
\cline { 2 - 4 } & Ingressos & Saídas & Saldo \\
\hline 1991 & $4.263,5$ & $9.999,4$ & $(5.735,9)$ \\
\hline 1992 & $2.791,5$ & $8.389,3$ & $(5.597,8)$ \\
\hline 1993 & $8.573,6$ & $14.902,4$ & $(6.328,8)$ \\
\hline 1994 & $8.140,3$ & $13.314,2$ & $(5.173,9)$ \\
\hline 1995 & $15.659,3$ & $19.707,4$ & $(13.037,8)$ \\
\hline 1996 & 247,1 & $13.284,9$ & $(20.897,7)$ \\
\hline 1997 & 638,8 & $21.536,5$ & $(23.172,2)$ \\
\hline $1998^{*}$ & $2.110,9$ & $25.283,1$ & $(83.992,2)$ \\
\hline Total & $42.425,0$ & $126.417,2$ & \\
\hline
\end{tabular}

Fonte: Revista do TCU (2001). 
Tabela 4 - Número de operações CC-5 por tipo e faixa de valores

\begin{tabular}{c|c|c|c|c|c|c|c|c|c|c}
\hline \multirow{2}{*}{ Ano } & \multicolumn{2}{|c|}{$\begin{array}{c}\text { Abaixo de } \\
\text { US\$ 10 mil }\end{array}$} & \multicolumn{2}{c|}{$\begin{array}{c}\text { De US\$10 a } \\
\text { US\$ 500mil }\end{array}$} & \multicolumn{2}{c|}{$\begin{array}{c}\text { De US\$500 a } \\
\text { US\$ I milhão }\end{array}$} & \multicolumn{2}{c|}{$\begin{array}{c}\text { Acima de } \\
\text { US\$ I milhão }\end{array}$} & \multicolumn{3}{|c}{ Total } \\
\cline { 2 - 12 } & ingresso & saída & ingresso & saída & ingresso & saída & ingresso & saída & ingresso & saída \\
\hline 1992 & 459 & 536 & 1.101 & 1.218 & 123 & 148 & 279 & 299 & 1.962 & 2.201 \\
\hline 1993 & 474 & 427 & 4.061 & 4.750 & 476 & 747 & 890 & 1.454 & 5.901 & 7.378 \\
\hline 1994 & 540 & 413 & 4.677 & 3.835 & 592 & 492 & 1.321 & 1.130 & 7.130 & 5.870 \\
\hline 1995 & 363 & 553 & 7.013 & 7.171 & 1.239 & 1.193 & 3.900 & 3.845 & 12.515 & 12.762 \\
\hline 1996 & 175 & 442 & 6.707 & 13.221 & 970 & 1.869 & 3.169 & 3.569 & 11.021 & 19.101 \\
\hline 1997 & 1.579 & 13.590 & 12.942 & 27.758 & 1.436 & 2.417 & 3.571 & 4.348 & 19.528 & 48.113 \\
\hline $1998^{*}$ & 414 & 567 & 13.533 & 18.733 & 1.485 & 2.252 & 4.213 & 3.835 & 19.645 & 25.387 \\
\hline Total & 4.004 & 16.528 & 26.499 & 46.521 & 5.083 & 6.059 & 8.961 & 8.492 & 39.212 & 73.547 \\
\hline
\end{tabular}

Fonte: Revista do TCU (200I).

$\mathrm{Na}$ tabela 3, podemos constatar um aumento no número de contas CC-5 nos anos 1990, bem como o aumento no número de operaçóes. Com relação à composiçáo das operaçóes acima de R $\$ 500$ mil entre 1996 e 1998, as operaçóes de depósito e câmbio visando à saída foram as mais utilizadas, caracterizando a necessidade de acomodaçáo dos recursos e de fuga de capitais para fora do país (TCU, 2001). Já na tabela 5 , percebemos que há uma concentração de valores em poucos clientes, de julho de 1996 a novembro de 1998.

Tabela 5 - Depositantes por número de operações CC-5 de 1\%/07/96 a 27/I I/98

\begin{tabular}{l|c|c|c|c|c|c|c}
\hline \multicolumn{4}{c|}{ Total Geral } & \multicolumn{4}{c}{ Apenas Foz do Iguaçu } \\
\hline$N^{\circ}$ OPS & Quant. & Valor & Clientes & Quant. & Valor & Clientes & Foz/Total \\
\hline I & 953 & 4.564 .949 & 953 & 40 & 53.476 & 40 & $1,2 \%$ \\
\hline 2 & 732 & 3.385 .758 & 366 & 38 & 50.988 & 19 & $1,5 \%$ \\
\hline 3 a 5 & 973 & 5.157 .303 & 264 & 93 & 108.583 & 27 & $2,1 \%$ \\
\hline 6 a 10 & 953 & 7.662 .835 & 129 & 109 & 140.050 & 15 & $1,8 \%$ \\
\hline II a 25 & 1.301 & 8.087 .728 & 83 & 370 & 465.373 & 23 & $5,8 \%$ \\
\hline 26 a 50 & 1.032 & 4.663 .544 & 29 & 88 & 172.958 & 2 & $3,7 \%$ \\
\hline 5I a 100 & 875 & 8.526 .230 & 12 & 120 & 146.382 & 2 & $1,7 \%$ \\
\hline I0I a 200 & 807 & 6.567 .264 & 6 & 115 & 151.586 & 1 & $2,3 \%$ \\
\hline + de 200 & 4.721 & 11.409 .488 & 7 & 2.592 & 8.525 .227 & 4 & $74,7 \%$ \\
\hline Total & 12.347 & 60.025 .099 & 1.849 & 3.565 & 9.814 .623 & 133 & $16,4 \%$ \\
\hline
\end{tabular}

Fonte: Revista do TCU (200I). 
A partir da tabela 5, verificamos que, de 1.849 clientes, os que fizeram a maior quantidade de operaçóes (de 11 a mais de duzentas operaçóes) foram apenas 137 clientes (perfazendo apenas 7,4\%), mas que movimentaram $\mathrm{R} \$ 39.254 .254$ bilhóes (65\%) de um total de $\mathrm{R} \$ 60.025 .099$ bilhóes. Registre-se também que, entre os 1.712 clientes esporádicos (92,5\%), que fizeram até dez operaçóes, depositaram-se cerca de R \$ 20,7 bilhóes (35\% do montante). O relatório do TCU registrou também que, de julho de 1996 a novembro de 1998, a cidade de Foz do Iguaçu representou 16,4\% do total de depósitos CC-5 no país.

No governo Lula (2003-2010), deu-se continuidade ao que já se fazia no governo Fernando Henrique Cardoso, ou seja, flexibilizou-se o envio de dinheiro ao exterior. Logo no início do mandato de Lula, em 16 de abril de 2003, publicou-se a Circular no 3.187 do Banco Central, que permitiu remessas de dinheiro ao exterior através de simples transferência eletrônica. Tal medida dificultou a fiscalização através do conceito know your costumer.

Em 2005, um pacote de medidas (Resoluçóes no 3.265 e no 3.266) foi aprovado pelo Banco Central. No dia 4 de março desse ano, foram aprovadas a unificação dos dois mercados cambiais, o livre e o flutuante; a extinção da Conta de Náo Residentes, facilitando as remessas de recursos para o exterior; e a dilatação de prazo para a cobertura cambial nas exportaçóes. Em fevereiro de 2006, a Medida Provisória no 281 sancionou a concessão de incentivos fiscais aos investidores estrangeiros para a aquisiçáo de títulos da dívida pública interna (GHINIS, 2006).

Como a extinçáo das contas de náo residentes (as CC-5) facilitou a remessa de dinheiro para o exterior? Segundo Ghinis,

A extinção das contas CC5 significa uma liberalização adicional das saídas de capitais, uma vez que elimina os limites para que pessoas físicas e jurídicas convertam reais em dólares e os remetam ao exterior. Na realidade, agora, qualquer residente no País pode efetuar suas remessas diretamente, sem intermediários. Anteriormente, os recursos deviam ser enviados para o exterior por intermédio de contas abertas por instituições financeiras não residentes em instituições financeiras residentes (contas CC5). (GHINIS, 2006, p. 104- 105, grifo nosso).

Outras medidas liberalizantes no governo Lula foram destacadas por Ghinis (2006), como a ampliaçáo dos prazos de retenção de dólares no exterior pelos exportadores (Resoluçáo no 3.266/2005). Dessa forma, tal medida 
contribuiu para a diminuiçáo da entrada de dólares no país e apontou para o fim da obrigaçáo dos exportadores de converter suas receitas em dólares para moeda nacional. A entrada de dólares no Brasil passou entáo a ser determinada muito mais por movimentos especulativos (atraçáo do capital externo pelas altas taxas de juros) do que por movimentos de saldos comerciais (a "economia real"). Com a unificaçáo dos mercados de câmbio (de taxas livres e de taxas flutuantes), segundo Ghinis,

[...] a partir de março de 2005, com a unificação dos mercados de câmbio, a capacidade do Banco Central de separar os fluxos de dólares referentes ao comércio e a investimentos diretos (antigo mercado de taxas livres) de fluxos de dólares financeiros especulativos (antigo mercado de taxas flutuantes) tornou-se limitada. Além disso, a concessão de incentivos fiscais aos investidores estrangeiros para a aquisição de títulos da dívida pública interna provocou um acelerado crescimento desse tipo de operação (GHINIS, 2006, p. 112).

Algumas das medidas aprovadas pelo governo Lula, como a autorizaçáo para que pessoas físicas e jurídicas possam comprar ou vender moedas, ou realizar transferências internacionais em reais, de qualquer natureza, sem limitação de valor, ficando dispensadas da autorização prévia do Banco Central, autorizaçáo esta que existia antes da referida resoluçáo, sáo medidas semelhantes às adotadas no Peru, na Colômbia e no México nos anos 1980/1990. Tais medidas permitem que o dinheiro do mercado negro ou do mercado paralelo (que pode ser do narcotráfico, de corrupçáa, de caixa dois, de propinas) possa ser lavado com relaxamento de fiscalização, apesar de a Resoluçáo $n^{\circ} 3.265 / 2005$ formalmente manter a necessidade de fiscalizaçáo de transaçóes superiores a $\mathrm{R} \$ 10 \mathrm{mil}$.

Outras medidas destacadas por Ghinis (2006), como os investimentos diretos no exterior, que eram permitidos até o limite de US\$ 5 milhóes num período náo inferior a um ano e que foram revogados; o fim da obrigatoriedade do retorno desses recursos, que podem agora ser livremente aplicados no exterior; o fim da obrigatoriedade de envio ao Banco Central de qualquer comprovaçáo de documento nas operaçóes relacionadas ao investimento direto no exterior; permitem um aumento da evasáo de divisas e a possibilidade de sub ou superfaturamento nas exportaçóes para se realizar a lavagem de dinheiro.

As facilitaçóes para a evasáo de divisas, assim como o comércio ilícito (narcotráfico incluído) e a lavagem de dinheiro são oriundos de decisōes políticas 
(NAÍM, 2006; SEVARES, 2003). No entanto, tais decisóes políticas, que visam facilitar a circulação de capitais, são uma necessidade econômica do capitalismo financeiro global, em que os mecanismos de circulação de dinheiro (D-D') são mais importantes que os investimentos "reais".

No Brasil, assim como nos demais países da América Latina, a adoção de políticas econômicas pró-fluxos de capitais externos para os países chamados "em desenvolvimento" foi marcada pelo mercado dos títulos da dívida pública (o principal segmento do mercado financeiro internacional) e pelas altas taxas de juros nesses países. No entanto, a alternância no ciclo de abundância e a escassez de capitais estrangeiros náo sáo determinadas pelas necessidades da "economia real". Nesse contexto de necessidade de liquidez, é interessante que capitais oriundos de anistias tributárias, propinas, tráficos de drogas, armas e demais mercadorias estejam livres para circulação e possam mesclar-se com os capitais "lícitos".

\section{Instrumentos de regulamentação}

Entre os órgáos de regulamentação internacionais sobre lavagem de dinheiro e crime organizado, destacam-se as "40 recomendaçóes" do Gafi/FATF (Grupo de Açáo Financeira sobre Lavagem de Dinheiro/Financial Action Task Force), o Grupo de Egmont (órgáo de coordenação entre unidades de inteligência financeira) criado em 1995, as Convençóes de Viena de 1988 e a de Palermo de 2000, das Naçóes Unidas.

O Gafi foi criado em 1989 pelo grupo dos sete países mais ricos do mundo (o G-7), com a finalidade de examinar, desenvolver e promover políticas de combate à lavagem de dinheiro. Em 1990, o grupo publicou as "40 Recomendaçóes", com o intuito de estabelecer açóes a serem seguidas pelos países imbuídos do propósito de combater o crime de lavagem de dinheiro. Duas das metas principais são fornecer instrumentos para o desenvolvimento de um plano de açáo de combate à lavagem de dinheiro e discutir açóes ligadas à cooperação internacional.

As medidas de regulamentação emergiram no final dos anos 1980 e início dos anos 1990, mais ou menos dez anos após o boom do narcotráfico nos anos 1970. Nesta década, os Estados Unidos criaram pela primeira vez uma lei (Lei Ricco) para fiscalizar a vigilância nos depósitos, obrigando as instituiçóes bancárias 
a declarar depósitos iguais ou superiores a US\$ 10 mil. A comunidade bancária dos Estados Unidos opunha-se a essa lei e chegou a processar o governo norte-americano, argumentando que ela era inconstitucional, tendo em vista que violaria o direito à privacidade de seus clientes (MORRIS, 1999).

A lavagem de dinheiro foi tipificada como crime pela primeira vez em 1981 na Alemanha, em 1986 nos Estados Unidos e, no Brasil, em 1998 (Lei $n^{\circ}$ 9.613/1998). Na adoção de legislaçóes sobre lavagem de dinheiro, houve uma ampliaçáo de legislaçóes "de primeira geraçáo", que vinculavam a lavagem de dinheiro apenas ao narcotráfico (Convençáo de Viena de 1988), para legislaçóes de "segunda geraçáo" (com elaboração de "crimes antecedentes", passíveis de lavagem) e para legislaçóes de "terceira geraçáo" (que ampliam a concepção de que toda ação que possa produzir dinheiro é passível de lavagem). O Brasil estaria enquadrado entre a segunda e a terceira geraçáo.

Considerando os principais instrumentos internacionais, como as " 40 recomendaçóes" do Gafi, a Conferência de Palermo organizada pela Organizaçáo das Naçóes Unidas (ONU) em 2000, a criaçáo de unidades de inteligência financeira (Financial Intelligence Units, FIUs), as pesquisas e açôes de coordenaçáo feitas pelo UNODC, há realmente um esforço no sentido de se questionar o sigilo bancário e um esforço no combate à lavagem de dinheiro e na defesa da assistência judiciária recíproca. No âmbito das instituiçóes financeiras (Acordo de Basileia, recomendaçóes da Felaban e Febraban), desenvolveram-se mecanismos de compliance (mecanismos internos de autorregulaçáo referentes à lavagem de ativos).

Em 1988, o Comitê da Basileia apresentou a International Convergence of Capital Measurement and Capital Standards. Sua finalidade era "proporcionar maior transparência, segurança e estabilidade às negociaçóes de bancos internacionais" (COSTA, 2004, p. 27). O princípio do know your costumer apareceu então como preocupaçáo das instituiçóes financeiras. Segundo o documento Os princípios essenciais da Basileia, do Comitê de Supervisão Bancária da Basileia subscrito pelo G-10 e ministros das finanças do G-7 em 1997,

Princípio 15: Os supervisores bancários devem determinar que os bancos adotem políticas, práticas e procedimentos, incluindo regras rígidas do tipo 'conheça-seu-cliente', que promovam elevados padrões éticos e profissionais no setor financeiro e previnam a utilização dos bancos, intencionalmente ou não, por elementos criminosos. (CÔMITE..., 1997, p. 25).

O know your costumer implica importantes medidas de fiscalização que devem ser seguidas pelos bancos, com a adoçáo de uma série de recomendaçóes 
elaboradas pelo Gafi (mas que náo têm poder normativo sobre as legislaçóes dos Estados aderentes, são orientaçóes), a criação de tipologias de lavagem de dinheiro, de indicadores para supervisão bancária, de supervisão pelas unidades de inteligência financeira. Entre as medidas do know your costumer baseadas nas "40 recomendaçóes" do Gafi, estáo:

a) Grandes movimentações de dinheiro em espécie;

b) Transferência atípica ou não justificável de recursos de/para jurisdições estrangeiras;

c) Transação ou atividade comercial estranha;

d) Movimentações grandes e/ou rápidas de recursos;

e) Riqueza incompatível com o perfil do cliente;

f) Atitude defensiva em relação a perguntas.

A respeito das unidades de inteligência financeira, analisamos dados de relatório do Conselho de Controle de Atividades Financeiras (Coaf), o principal órgáo brasileiro responsável pela inteligência financeira, subordinado ao Ministério da Fazenda. O Coaf foi criado pela Lei no 9.613/1998, lei esta que regulamentou as medidas antilavagem de dinheiro no Brasil. O Artigo $1^{\circ}$ da referida lei abrange a "ocultaçáo, dissimulaçáo, conversão, transferência, aquisiçáo, posse e uso de proventos" como os mecanismos tipificados como lavagem de dinheiro. Em seguida, o Brasil tornou-se membro do Grupo de Egmont, em 1999, organismo internacional de cooperaçáo entre as Fius. O Coaf é uma dessas Fius.

O Coaf, conforme seu próprio relatório (BRASIL, 2009), não tem a atribuição legal de controlar todas as diversas atividades financeiras que acontecem diariamente no Brasil, náo recebe ou analisa contratos e tampouco tem acesso às contas ou investimentos dos cidadáos. Os relatórios do Coaf fazem menção às porcentagens de bancos e instituições financeiras que nunca fizeram comunicaçóes suspeitas, mas náo apresentam nomes nos seus relatórios públicos. No âmbito da inteligência financeira, o órgáo desenvolveu uma matriz de riscos para verificar se as empresas realizam procedimentos de identificaçáo, registro, controle de operaçóes e controle de clientes.

De 1998 a 2009, foram realizadas 3.053.251 comunicaçóes ao Coaf. O sistema bancário representa a principal fonte de informaçóes: foram 1.194.379 comunicaçóes de bancos (cerca de 39\%) de um total de 3.053.251 comunicaçôes de instituiçóes financeiras. Apenas em 2009, ano em que explodiu a crise financeira global, ocorreu um montante de 1,5 milhão de comunicaçóes suspeitas ou 45\% de todas as comunicaçóes recebidas no período 1998-2009, conforme dados apresentados na tabela 6 . 


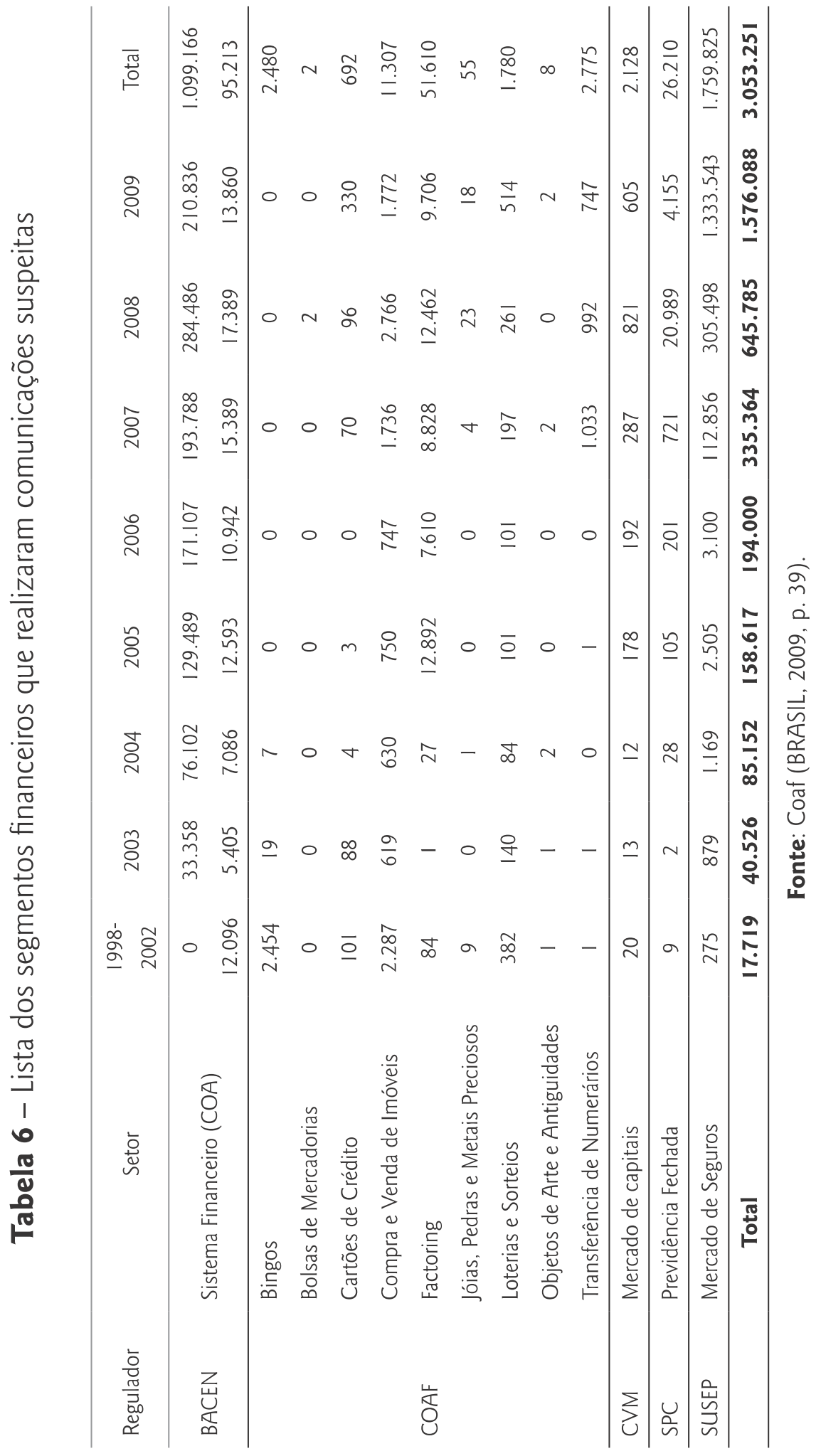


Segundo o relatório, de 159 instituiçóes financeiras, 48 (30,18\%) nunca enviaram comunicaçóes ao Coaf. Dessas 159, 111 são bancos e 48 são instituiçóes financeiras náo bancárias. De 111 bancos, observou-se que 17 dessas instituiçóes nunca fizeram qualquer comunicação de operação suspeita. Importante destacar que, no relatório público do Coaf, não há menção nominal aos bancos que nunca fizeram comunicaçóes suspeitas, pois o órgão considera que seus dados sáo sigilosos.

Outro aspecto a se destacar de acordo com os dados do Coaf é que, das 1.194.379 comunicaçóes atípicas de bancos (cerca de 39\% do total dos segmentos financeiros), a esmagadora maioria foi de operaçôes em espécie (sigla Coas: Comunicaçóes de Operaçóes Automáticas-Espécie), com cerca de 92\% (1.099.166) do total de operaçóes atípicas dos bancos, ante 7,97\% (95.213) de comunicaçóes de operaçóes suspeitas (sigla COS). O fato de a maioria das comunicaçóes suspeitas ser em espécie (cédulas de baixo valor) deve-se ao fato de que a comercialização de mercadorias ilícitas, ao adentrar no sistema bancário, faz-se pelo método do fracionamento dos depósitos, como mecanismos de se burlar o rastreamento.

Outra medida de controle é a Circular no 3.461/2009 do Banco Central, que define o conceito de "peps" (pessoas politicamente expostas), conceito que estava previsto nas recomendaçóes do Gafi (Artigo 60), que é tipificado como "os agentes públicos que desempenham ou tenham desempenhado, nos últimos cinco anos, no Brasil ou em países, territórios estrangeiros, cargos, empregos ou funções públicas relevantes, assim como seus representantes e familiares". Esse conceito merece especial atenção, pois, segundo ele, as instituiçôes financeiras devem enviar relatórios sobre a movimentação financeira dessas pessoas.

Mas muitas lacunas foram identificadas no caso do Brasil, algumas delas elaboradas pelos próprios órgáos de fiscalizaçáo, que sintetizam um esforço de aperfeiçoamento dos mecanismos de regulação. Entre essas lacunas observadas pelo Relatório de Avaliaçáo Mútua do Gafisud/Gafi (2010) e por pesquisadores como Mink (2005), estáo:

a) as recomendações do Coaf náo têm caráter de obrigatoriedade no cumprimento das recomendaçóes, o Coaf não pode obrigar a produção de informaçóes específicas do cliente para efeitos de supervisáo sem ordem judicial (manutenção do sigilo bancário); 
b) o fato de que o Coaf náo pode obrigar as instituiçóes financeiras a cumprir as determinaçōes que foram elaboradas pelo Gafi;

c) o fato de, no Brasil, a responsabilidade penal sobre lavagem de dinheiro não se estender às pessoas jurídicas;

d) o fato de que não há menção à possibilidade de se atribuir responsabilidade criminal aos agentes do sistema financeiro, que, no desempenho de suas funçóes, foram cientes da origem ilícita do dinheiro de seus clientes;

e) o fato de náo existir nenhuma proibiçáo sobre o estabelecimento de "bancos de fachada" (bancos que existem num país, mas sem sede física no mesmo) e as instituiçóes financeiras não são proibidas, no Brasil, de manter relaçóes bancárias de correspondência com os bancos de fachada.

As açóes do Coaf são sintonizadas com as "40 recomendaçóes" do Gafi e do Grupo de Egmont. Tais organismos trabalham com o conceito know your customer. De acordo com esse conceito, a identificaçáo do cliente deve ser satisfatoriamente estabelecida antes da concretização da operaçáo. Caso o possível cliente se recuse a fornecer as informaçóes requeridas, a instituiçáo financeira náo deve aceitá-lo como cliente.

No âmbito do Estado, existe uma tensáo no capitalismo, expressa no binômio desregulamentação monetária/financeira versus tentativas de regulamentaçáo. A Comissáo Parlamentar de Inquérito (CPI) do narcotráfico de 2000 no Brasil, criada dois anos após a adoção da legislaçáo antilavagem no país, talvez expresse algumas dessas tensóes entre Estado e mercado. Em seu relatório final, a CPI destacou que 855 pessoas físicas e jurídicas tiveram o sigilo bancário quebrado, mas apenas 434 tiveram seus dados apresentados pelas instituiçóes financeiras. O relatório da CPI fez uma menção à não colaboraçâo da Receita Federal na análise de documentos e menção à negativa do HSBC em colaborar com a CPI. Foi demonstrada a existência de esquemas empresariais; os tentáculos dos grupos criminosos e conexóes com criminosos estrangeiros; a utilizaçáo de casas de câmbio; a existência de esquema de lavagem de dinheiro em imóveis; e a utilizaçáo de empresas insolventes. Com relação aos bancos e ao sistema financeiro, das mais de mil páginas do relatório da CPI, só há a referida mençáo ao HSBC em poucas linhas, assim como se faz menção em poucas linhas à negativa dos bancos em fornecer informaçóes, mas eles não são nominados. Segundo Magalhães (2000), a CPI só investigou 
atores de pequeno e médio porte, empresários e políticos de poder limitado, além da participação de algumas dezenas de policiais militares.

Apesar de várias medidas de regulamentação/fiscalização (muitas delas no campo apenas da recomendaçáo), apenas 0,2\% do dinheiro ilícito é apreendido no sistema financeiro mundial, motivo de grande lamentaçáo e preocupação do UNODC em documento de 2011.

As proporçôes da lavagem de dinheiro de diversas atividades ilícitas são estimadas em torno de 70\% (cerca de US\$ 1,6 trilháo de uma receita de US\$ 2,1 trilhóes). No caso das drogas ilícitas, cerca de $20 \%$ das receitas do crime organizado global estariam ligados ao narcotráfico (estimativa de US\$300 a US\$ 500 bilhóes).

$\mathrm{Na}$ América Latina, com as políticas exigidas pelo FMI de flexibilização cambial, flexibilização da entrada/saída de capitais, sobrevalorização das moedas locais no Peru, Bolívia, México e Colômbia nos anos 1980-1990 e desvalorização do dólar, permitiu-se que os narcodólares em abundância pudessem entrar e sair.

Como destacado anteriormente, várias lacunas permitem que se burlem os esforços de fiscalizaçáo da lavagem de dinheiro. As consideraçóes levam à reflexão sobre o papel do Estado. A análise realizada nos conduz à afirmaçáo de que o Estado náo é uma entidade "ausente" e o narcotráfico e as demais atividades criminosas, "Estados paralelos". Cientistas sociais que estudam crime organizado (OLIVEIRA, 2008; MISSE, 1997; MORAIS, 2006) destacam a existência de uma simbiose entre crime organizado e segmentos do aparelho de Estado como condição necessária ao desenvolvimento das atividades ilícitas e criminosas.

\section{Conclusões}

O Estado no capitalismo é uma estrutura jurídico-política em permanente contradição, expressa na tensão entre desregulação do movimento de capitais versus tentativas de fiscalização do dinheiro ilícito e de atividades criminosas.

Quando olhamos para os principais instrumentos internacionais de fiscalização, como as "40 recomendaçóes" do Gafi, a Conferência de Palermo e a criaçáo de unidades de inteligência financeira, temos a impressáo de que é 
possível, nos marcos do capitalismo, combater/fiscalizar a gama de atividades ilícitas. No entanto, o fato de que apenas $0,2 \%$ do dinheiro ilícito é apreendido em âmbito global nos conduz à percepção de que as atividades ilícitas e criminosas estariam na verdade perfeitamente integradas na atual dinâmica de acumulaçáo de capital.

A desregulamentação financeira e monetária significou uma ação deliberada do capital financeiro, intensificada a partir da ruptura do padráo-ouro de 1971, ao se iniciar a derrubada de alguns entraves no terreno jurídico para a produçáo de uma "nova regulaçáo". A burguesia necessitou e necessita de uma açáo deliberada do Estado para permitir a maximizaçáo dos lucros do capital (regulamentação dos paraísos fiscais, das sociedades offshore, políticas de desvalorizaçáo cambial, redução de impostos). Porém, o que destaco é que o Estado é uma condiçáo necessária para a chamada "desregulamentaçáo" do movimento de capitais.

A economia da droga na América Latina expandiu-se a partir de determinados processos de desregulamentaçáo e liberalizaçáo monetária e financeira. Segundo Harvey, os capitalistas buscam constantemente criar novos espaços e campos de acumulaçáo:

Na ausência de quaisquer limites ou barreiras, a necessidade de reinvestir a fim de continuar a ser um capitalista impulsiona o capitalismo a se expandir a uma taxa composta. Isso cria então uma necessidade permanente de encontrar novos campos para absorver o capital reinvestido: daí 'o problema da absorção do excedente de capital'. De onde virão as novas oportunidades de investimentos? (HARVEY, 2012, p. 45).

Nossa resposta à pergunta de Harvey é: das drogas ilícitas. Nesse contexto, os narcodólares, que representam cerca de $20 \%$ das receitas do crime organizado mundial, estimado em US\$ 2,1 trilhóes, atrás apenas da evasáo fiscal, segundo a UNODC, cumprem um papel significativo na criação de novos espaços e campos de acumulaçáo.

Atores ligados ao sistema financeiro, como o especulador George Soros e o economista defensor do livre-mercado Milton Friedmann (1912-2006) assessor nos governos de Reagan, Tatcher e Pinochet - tornaram-se defensores da legalizaçâo das drogas ilícitas. No caso de Milton Friedmann, "de todas as drogas". ${ }^{3}$ Um dos argumentos seria que "o governo deixaria de gastar milhóes

3 Reportagem: "Legalize já - a maconha -, diz Friedman, 92". Entrevista com Milton Friedmann publicada na Folha de São Paulo/Folha On Line, em 19/06/05. Nessa entrevista. Friedmann afirma: "sou a favor da legalização de todas as drogas, não apenas da maconha". 
em policiamento e arrecadaria milhóes de impostos" ${ }^{4}$ A cobrança de taxas sobre o negócio das drogas é apresentada como justificativa para supostamente se combater o déficit público (mas que também pode servir de meio para se obter mais recursos para se pagar a dívida pública). Essa foi a motivação de prefeituras nos Estados Unidos (em 2010) e na Espanha (2012), que passaram a defender tais proposiçóes. Com a legalização da produção, podemos supor que proliferariam diversas formas de produção, desde o pequeno e microcomércio, através do autoplantio e de cooperativas, até os interesses do agronegócio.

George Soros, defensor da legalizaçáo, já foi acusado de envolvimento, na Colômbia, em uma rede de lavagem de dinheiro do narcotráfico. A relaçáo é muito mais profunda. Soros foi acusado de se envolver com dinheiro do narcotráfico desde 1994, ao que ocorreu a privatização do Banco de Colômbia (Banco de La República), que foi vendido à família Gilinski, que já havia comprado anteriormente ativos do Banco de Colômbia que estavam no recém-falido Banco de Comércio e Crédito Internacional (BCCI). O BCCI era um conhecido e enorme banco que operou de 1972 a 1991, que possuía implantaçáo em cinco continentes, com 73 filiais, e que esteve envolvido com dinheiro de diversas atividades criminosas - drogas, armas, terrorismo, evasão fiscal, petróleo, sociedades industriais, comerciais, companhias de seguros -, chegando a gerir as reservas dos Bancos Centrais de países com grande PIB, como a Nigéria (ZIEGLER, 1998).

A família Gilinski comprou o Banco de Colômbia por cerca de US\$ 400 milhóes, numa das maiores privatizaçóes do sistema bancário. O Banco de Colômbia era acusado de processar dinheiro oriundo do narcotráfico, ligado ao Cartel de Cáli. Em maio de 1994, a família Gilinski vendeu 9\% do banco para George Soros, que investiu algo em torno de US\$ 70 a US\$ 80 milhóes. A família Gilinski foi acusada de envolvimento com traficantes colombianos e russos em negócios de drogas e armas.

O eixo bancário internacional que havia sido formado por Soros e a família Gilinski foi identificado em 2000, por agentes da Drug Enforcement Agency (DEA), dos Estados Unidos. No ano em que Soros e a família Gilinski assumiram o Banco de Colômbia, ocorreram atritos com o governo dos Estados

4 Idem. 
Unidos, que se posicionaram contra o que ficou conhecido a "narcoaquisiçáo" desse banco. A administração Clinton, o Departamento de Justiça e o senador democrata John Kerry pressionaram Gustavo de Greiff, promotor-chefe da Colômbia de 1992 a 1994, acusado também de envolvimento com o Cartel de Cáli. Nessa época, o presidente Ernesto Samper (1994-1998) foi acusado de ter sua campanha presidencial financiada pelo Cartel de Cáli. Gustavo de Greiff é um dos porta-vozes de um movimento de legalizaçáo das drogas impulsionado por Soros, operado por várias entidades de Soros na América do Norte e do Sul (como o grupo de Law Enforcement Against Prohibition ${ }^{5}$ ), reunindo as forças de lobby dos produtores de narcóticos e os seus financiadores. Soros e Gilinski náo possuem mais o controle do Banco de Colômbia, ${ }^{6}$ chamado agora BanColômbia. ${ }^{7}$

Nos Estados Unidos, a maconha já renderia US\$ 35 bilhóes ao ano, um crescimento de dez vezes em 25 anos. ${ }^{8}$ Sementes geneticamente modificadas têm resultado em colheitas antecipadas, vendas e lucros maiores. A maconha em escala agroindustrial tem superado o milho e o trigo estadunidense e canadense. Esses valores explicam o porquê de tantas Organizaçóes Náo Governamentais (ONGs) estarem interessadas na legalizaçáo das drogas, sobretudo da maconha.

Contudo, será que a legalizaçáo e a produçáo e consumo de drogas seriam meios mais eficazes para se combater o narcotráfico e o consumo excessivo? A legalizaçáo pode acarretar uma maior socializaçáo dos custos sociais e econômicos, além da tendência de aumento do consumo. Taxar (impostos) a produçáo das drogas ilícitas poderá "não fechar a conta", pois, além dos gastos em saúde pública, essa política de taxas pode servir para se arrecadar fundos para se pagar os títulos da dívida pública, diante do crescente déficit fiscal.

50 banco possui filial no Brasil, através da Leap-Brasil. Disponível em: <http://www.leapbrasil.com.br/quemsomos/a-leaps.

6 Informações no artigo "George Soros, chief funder and controller of the campaign to legalize narcotics, has been caught in the banking network that launders the criminal proceeds of dope sales", 25/02/2009. Disponivel em: <http://forum. prisonplanet.com/index.php?topic=88965. msg5 /4443\#msg5 /4443>.

7 Gilinski Estarían Trás El HSBC em Suramerica, 08/05/20/2. Disponivel em: <http://www.portafolio.co/negocios/gilinski-estarian-el-hsbc-suramerica>.

8 Entre 198I e 2006, a produção de maconha dos Estados Unidos aumentou dez vezes, de mil toneladas para mais de 10 mil toneladas, de acordo com dados do relatório Marijuana Production in the United States (GETTMAN, 2006). 
A despenalizaçáo ou a descriminalizaçáo do consumo sáo políticas vistas hoje pela ONU como mais racionais. Trata-se de pensar o indivíduo que por ventura torna-se dependente químico como um foco de saúde pública e náo de repressão.

Mas será que a questấo do tráfico e da violência que é gerada se resolve com a despenalizaçáo e a descriminalizaçáo? Os tráficos podem perfeitamente migrar de ramo. Legalizar parcialmente a produçáo de apenas algumas drogas ilícitas (maconha, por exemplo) pode náo impedir que estas continuem sendo produzidas/vendidas pelo tráfico (o álcool e o cigarro são drogas legalizadas, o que náo impede o tráfico dessas mercadorias). É razoável duvidarmos se, com a legalizaçáo de algumas drogas ilícitas, o tráfico se enfraquecerá. Por outro lado, legalizar todas as drogas ilícitas (incluindo as mais pesadas, como cocaína, heroína, crack) pode criar um grave problema de saúde pública.

Entendemos o narcotráfico como subproduto de um parasitismo econômico, identificado com a atual lógica de acumulaçáo global. Os agricultores na regiáo andina, na Colômbia, no Afeganistáo, os jovens soldados do tráfico nos grandes centros urbanos, que encontram no narcotráfico uma fonte de sustento, náo se libertam da situaçáo de pobreza, muito menos tais atividades trazem "prosperidade econômica" para essas comunidades. Ao contrário, a multiplicação dos preços das drogas dos países produtores até os países consumidores cria uma enorme assimetria de poder econômico. A legalizaçáo da produçáo e consumo de drogas ilícitas resultaria em desenvolvimento econômico? Responder a essa importante questáo implica levar em conta os atuais mecanismos de acumulaçáo.

As análises realizadas nos conduzem a afirmar que o capital está interessado em atividades que rendam no tempo mais breve possível. Investimentos produtivos (criaçáo de empregos, expansáo e melhoria de serviços públicos, investimentos na agricultura, melhoria nos índices de desenvolvimento humano) exigem um maior aporte de recursos do Estado. No entanto, o déficit fiscal que está no centro do debate político e econômico atual é oriundo muito mais de isençóes fiscais e pagamento de juros dos títulos públicos do que de "gastos excessivos" do Estado.

A atual crise estrutural do capital tem levado os capitalistas a tentar resolver o problema da sobreacumulação. O renomado geógrafo David Harvey em $O$ 
enigma do capital pergunta de onde viráo novas oportunidades de investimentos aos capitalistas. A destruição de capacidades produtivas (empregos) tem sido a marca do atual capitalismo financeiro, condicionando os investimentos públicos estatais. Num mundo onde tudo é transformado em mercadoria, a apropriaçáo pelo capital da produçáo e consumo de diversas drogas é influenciada por uma lógica: a manutençáo dos lucros e, para isso, a manutençáo de altos níveis de consumo.

\section{Fontes}

BRASIL. Congresso Nacional. Relatório da Comissáo Parlamentar Mista de Inquérito (CPMI) destinada a investigar o avanço e a impunidade do narcotráfico. Brasília, DF, nov. 2000. 1.198 p. BRASIL. Conselho de Controle de Atividades Financeiras. Ministério da Fazenda. Cartilha do COAF. 2005. 20 p. Disponível em: <https://www.coaf.fazenda.gov.br/conteudo/publicacoes>. Acesso em: 15 jun. 2011.

BRASIL. Lei n. 9.613, de 3 de março de 1998. Dispôe sobre os crimes de "lavagem" ou ocultação de bens, direitos e valores; a prevenção da utilização do sistema financeiro para os ilícitos previstos nesta Lei; cria o Conselho de Controle de Atividades Financeiras - COAF, e dá outras providências. Brasília, DF, 1998. Disponível em: <https://www.coaf.fazenda.gov.br>. Acesso em: 15 jun. 2011.

BRASIL. Ministério da Fazenda. COAF (Conselho de Controle de Atividades Financeiras). Prestação de Contas Ordinária Anual. Relatório de Gestáo do Exercício de 2009. 65 p. Disponível em: <https://www.coaf.fazenda.gov.br/conteudo/publicacoes/relatorios-coaf/>. Acesso em: 15 jun. 2011.

BRASIL. Revista do TCU (Tribunal de Contas da Uniáo), v. 32, n. 89, 137 p., jul./set. 2001. Disponível em: <http://portal2.tcu.gov.br/portal/pls/portal/docs/683670.PDF>. Acesso em: 15 jun. 2011.

COMITÊ DE SUPERVISĀO BANCÁRIA DA BASILEIA. Os princípios essenciais da Basileia. Tradução de Banco Central do Brasil. Brasília, set. 1997. 41 p.

FATF/GAFI. Financial action task force on money laundering. Grupo de açáo financeira sobre o branqueamento de capitais. As 40 recomendaçóes do GAFI, 1990.

Disponível em: <https://www.coaf.fazenda.gov.br/conteudo/publicacoes>. Acesso em: 15 jun. 2011.

FELABAN. Declaración de principios de la Federación LatinoAmericana de Bancos del uso indebido del sistema financiero en el lavado de activos provenientes del narcotrafico y de octras actividades ilícitas. 1996. Disponível em: <http://www.felaban.com/coplaft/>. Acesso em: 15 jun. 2011. 
GAFISUD/GAFI. Relatório de avaliaçáo mútua. Sumário executivo. Prevençáo à lavagem de dinheiro e combate ao financiamento do terrorismo. República Federativa do Brasil, 25 jun. 2010. 26 p.

NAÇÓES UNIDAS. Convençáo contra o tráfico ilícito de entorpecentes e de substâncias psicotrópicas. 1988. (Convençáo de Viena).

NAÇÓES UNIDAS. Convençáo das Naçóes Unidas Contra o Crime Organizado Transnacional. 2000. (Conferência de Palermo).

UNODC (UNITED NATIONS OFFICE ON DRUGS AND CRIME). Estimating illicit financial flows resulting from drug trafficking and other transnational organized crimes. 2011. 140 p. Disponível em: <http://www.unodc.org/documents/.../Illicit_financial_flows_2011_ web.pdf>. Acesso em: 15 jun. 2011.

UNODC (UNITED NATIONS OFFICE ON DRUGS AND CRIME) Relatórios anuais disponíveis de 1997 a 2012. Disponível em: <http://www.unodc.org/>. Acesso em: 15 jun. 2011.

\section{Referências}

CAMPS, A. A droga, o tráfico e a lavagem de dinheiro. Revista A Verdade, Revista Teórica da IVa Internacional, 14 ago. 1995.

CERVINI, R. O processo de lavagem de dinheiro: as networks ilícitas de poder. In: RIBEIRO, M. de M.; SEIBEL, S. D. (Org.). Drogas: hegemonia do cinismo. São Paulo: Memorial, 1997. p. 191-216.

CHESNAIS, F. A mundializaçáo do capital. São Paulo: Xamã, 1996.

COGGIOLA, O. As razóes da droga na América Latina. 24 jun. 2005. Disponível em: <http:// www.universia.com.br/materia/materia.jsp?id=7499>. Acesso em: 15 jun. 2011.

Capitalismo, imperialismo e narcotráfico. In: Questóes de história contemporânea. Belo Horizonte: Oficina de Livros, 1991.

COSTA, J. N. Acordo de Basileia: impacto no comportamento das instituiçóes financeiras brasileiras. Brasília. Dissertaçáo (Mestrado em Economia). Universidade Católica de Brasília, 2004.

DEL ROIO, J. L. Mundialização e criminalidade. In: RIBEIRO, M. de M.; SEIBEL, S. D. (Org.). Drogas: hegemonia do cinismo. Sáo Paulo: Memorial, 1997.

DINO, A.; MAIEROVITCH, W. F. (Org.). Novas tendências da criminalidade transnacional mafiosa. Sáo Paulo: Unesp, 2010. 
GETTMAN, J. Marijuana production in the United States (2006). The Bulletin of Cannabis Reform, Issue Number 2, Dec. 2006. Disponível em: <http://www.drugscience.org/Archive/bcr2/ bcr2_index.html>. Acesso em: 15 jun. 2011.

GHINIS, C. P. O avanço do processo de liberalizaçáo financeira no governo Lula e o comportamento dos fluxos de capitais internacionais para o Brasil. Indicadores Econômicos FEE, Porto Alegre, v. 34, n. 2, p. 103-114, set. 2006.

GROSSE, R. Drugs and money. Laudering Latin America's cocaine dollars. USA: Praeger Publishers. Library of Congress, 2001.

HARVEY, D. O enigma do capital e as crises do capitalismo. São Paulo: Boitempo, 2012.

. O novo imperialismo. Sáo Paulo: Loyola, 2010.

JOBIM, N. A Lei no $\mathbf{9 . 6 1 3 / 9 8}$ e seus aspectos. Seminário Internacional Sobre Lavagem de Dinheiro. Conselho de Justiça Federal. Ministério da Fazenda/COAF. Brasília, DF, 29 e 30 de novembro de 1999.

LEAL, R. P. C.; RÊGO, R. B. Impacto do Anexo IV no Mercado de Capitais Brasileiro. Revista de Administraçáo da USP, v. 32, n. 3, p. 82-88, jul./set. 1997.

LIMA, M. C. México: os efeitos perversos do NAFTA. Ago. 2006. Disponível em: <http://www. acessa.com/gramsci/?id=536\&page=visualizar $>$. Acesso em: 15 jun. 2011.

MACHADO, L. O. O comércio ilícito de drogas e a geografia da interaçáo financeira. Depto de Geografia-UFRJ. Linha de pesquisa: A Geografia da Integraçáo Financeira Mundial: centros financeiros, centros "offshore", paraísos fiscais. s/d. Disponível em: <http://www.igeo.ufrj.br/ fronteiras/>. Acesso em: 15 jun. 2011.

. Movimento de dinheiro e tráfico na Amazônia. In: RIBEIRO, M. de M.; SEIBEL, S. D. (Org.). Drogas: hegemonia do cinismo. Sáo Paulo: Memorial, 1997.

MAGALHÃES, M. O narcotráfico. Sáo Paulo: PubliFolha, 2000. (Coleçáo Folha Explica).

MINK, G. F. C. Lavagem de dinheiro. Rio de Janeiro. Monografia (Graduaçáo em Direito). Universidade Federal do Rio de Janeiro, 2005.

MISSE, M. As ligaçóes perigosas: mercado informal ilegal, narcotráfico e violência no Rio. Contemporaneidade e Educaçáo, v. 1, n. 2, p. 93-116, maio 1997.

MORAIS, M. N. Uma análise da relaçáo entre o Estado e o tráfico de drogas: o mito do "poder paralelo". Ciências Sociais em Perspectiva, v.5, n. 8, p. 117-136, $1^{\circ}$ sem. 2006.

MORRIS, S. E. Açóes do combate à lavagem de dinheiro em outros países: experiência americana. Seminário Internacional Sobre Lavagem de Dinheiro. Conselho de Justiça Federal. Ministério da Fazenda/COAF. Brasília, DF, 29 e 30 de novembro de 1999. 
NAÍM, M. Ilícito: o ataque da pirataria, da lavagem de dinheiro e do tráfico à economia global. Rio de Janeiro: J. Zahar, 2006.

NOVAES, A. R. Tráfico de drogas e lavagem de dinheiro: um estudo sobre a atuaçáo das redes ilegais na Amazônia brasileira. Rio de Janeiro. Monografia. (Graduaçâo em Geografia). Universidade Federal do Rio de Janeiro, 2003.

OLIVEIRA, A. Tráfico de drogas e crime organizado. Peças e mecanismos. Curitiba: Juruá, 2008.

PEREIRA, T. C. O crime organizado transnacional e o tráfico de drogas no México. Brasília. Monografia (Especialização em Relaçóes Internacionais). Universidade de Brasília, 2010.

SANCHÉZ, H. C. Importancia económica del narcotráfico y su relación con las reformas neoliberales de Fujimori. In LASERNA, R. (Org.). Economia política de las drogas: lecturas latino-americanas. Cochabamba, Bolívia: Clacso, 1993. p. 113-134.

SEVARES, J. El capitalismo criminal. Buenos Aires: Norma, 2003.

UPRIMNY, R. Narcotráfico e poder: o caso colombiano. In: RIBEIRO, M. de M.; SEIBEL, S. D. (Org.). Drogas: hegemonia do Cinismo. Sáo Paulo: Memorial, 1997. p. 145-169.

WOODIWISS, M. Capitalismo gangster: quem săo os verdadeiros agentes do crime organizado mundial? Sáo Paulo: Ediouro, 2007.

ZIEGLER, J. Os senhores do crime: as novas máfias contra a democracia. Lisboa, Portugal: Terramar, 1998.

Recebido em: 26/07/2013

Aprovado em: 02/12/2013

\section{State, narcotrafficking and financial system: some approaches}

\section{Abstract}

We seek to make some links between the phenomenon of drug trafficking mechanisms of the financial system and deregulation in capitalism. Understanding the structural determinants of the expansion of the drug trade was an important element of analysis. Counterpose the measures of financial deregulation and monetary measures regulatory/oversight of illicit money, and examine whether there is interest of states/governments under capitalism in combat illicit capital.

Keywords: Drug trafficking. Money laundering. Financial system. 